\title{
Viral lysis and bacterivory as prokaryotic loss factors along a salinity gradient
}

\author{
Núria Guixa-Boixareu ${ }^{1, *}$, Juan I. Calderón-Paz ${ }^{1}$, Mikal Heldal $^{2}$, Gunnar Bratbak ${ }^{2}$, \\ Carlos Pedrós-Alió ${ }^{1}$
}

\author{
'Institut de Ciències del Mar, CSIC, Passeig Joan de Borbó s/n, E-08039 Barcelona, Spain \\ ${ }^{2}$ Department of Microbiology, University of Bergen, Jahnebakken 5, N-5020 Bergen, Norway
}

\begin{abstract}
We estimated prokaryotic mortality due to viruses and bacterivores through salinity gradients in 2 solar salterns. In each saltern system, successive ponds provided steady state environments with a range of salinities from 37 to $372 \%$. Prokaryotic and viral abundance increased with salinity, reaching about $10^{8}$ prokaryotic cells $\mathrm{ml}^{-1}$ and $10^{4}$ virus-like particles (VLP) $\mathrm{ml}^{-1}$ at salinities higher than $250 \%$. Prokaryotic doubling times became longer than $2 \mathrm{~d}$ above $250 \%$ salinity until the end of the gradient. Bacterivory accounted for all the production at lower salinities but it was found to be zero at the highest salinities. The percentage of visibly infected cells was not different among the ponds where infected cells could be detected and it was always lower than $4 \%$. From the percentage of infected cells and using conversion factors from the literature we estimated rates of prokaryotic mortality due to viral lysis: about 0.6 to $2 \times 10^{6}$ prokaryotes $\mathrm{ml}^{-1}$ were lysed daily by the viruses in the salterns. This number represented a low percentage of prokaryotic abundance and production compared to the prokaryotic losses due to bacterivores $\left(0.2\right.$ to $4 \times 10^{7}$ bacteria $\left.\mathrm{ml}^{-1} \mathrm{~d}^{-1}\right)$. However, viral production reached values higher than $10^{8}$ VLP $\mathrm{ml}^{-1} \mathrm{~d}^{-1}$ above $250 \%$ salinity, due to the large burst size (200 viruses cell ${ }^{-1}$ ) found in a particular morphotype of prokaryotes, the square archaea. These archaea represented more than $25 \%$ of the prokaryotic assemblage above $250 \%$ salinity. At this point they became the prokaryotic morphotype with the largest percentage of infected cells 11 to $10 \%$ of square archaea with visible phages inside). A lemon-shaped virus (simlar to one described for some other groups of archaea) was found infecting square archaea, its abundance increased in the saltiest ponds together with that of the square archaea. In this system viruses did not exert a strong control over the prokaryotic abundance and growth rate.
\end{abstract}

KEY WORDS: Phages Prokaryotic loss factors Bacterivory Solar salterns Halophilic archaea

\section{INTRODUCTION}

Understanding of the processes controlling prokaryotic assemblages in aquatic systems and measurement of the carbon fluxes through them have been hampered by methodological difficulties. Thus, the appearance of a reliable technique to measure bacterivory (Sherr et al. 1987) resulted in several studies indicating that predation of bacterioplankton by protozoans was the principal fate of bacterial production in different environments (Pace 1988, Sherr et al. 1989, Vaqué et

\footnotetext{
•E-mail: nuriag@icm.csic.es
}

al. 1993). However, once the consistent methodology to measure both parameters simultaneously was established, protozoan bacterivory did not always account for $100 \%$ of bacterial production (Sherr et al. 1989). In order to explain the constant cell concentration of bacterioplankton commonly found in natural waters over long periods of time, alternative loss factors of bacterioplankton had to be considered (Vaqué et al. 1993). Recently, viral lysis has been recognized as an important cause of bacterial mortality in both marine (Proctor \& Fuhrman 1990) and fresh waters (Hennes \& Simon 1995).

High percentages of bacterial mortality have been attributed to viral lysis in some environments (Proctor 
\& Fuhrman 1990, 1992, Heldal \& Bratbak 1991, Steward et al. 1992, Weinbauer \& Peduzzi 1994, 1995a). However, very few studies have attempted to balance bacterial production on the one hand and mortality including both protist predation and virus infection on the other (Bratbak et al. 1992, Fuhrman \& Noble 1995).

The objective of this work was to determine the influence of viruses on prokaryotic abundance and growth rate relative to that of bacterivores. Two approaches are possible to compare both sources of mortality simultaneously. In one approach, a natural community can be enclosed in a mesocosm, where all factors can be measured simultaneously under controlled conditions. Fuhrman \& Noble (1995) used this approach and found that bacterivory and viral lysis accounted for about $50 \%$ each of bacterial mortality in water sampled in coastal California (USA). In another approach, measurements can be done in a natural environment. This has the advantage of avoiding possible changes in the microbial community due to enclosure, the so-called bottle effects, which can be occasionally very important for viruses (Bratbak et al. 1992). The problem, on the other hand, is that the system may not be in steady state, and that advection or other uncontrolled factors may complicate interpretation of results. We decided to look for a natural system which resembled a mesocosm as much as possible. Further, we looked for a series of systems where we could expect the relative importance of bacterivory and viral lysis to change with respect to each other, so that the effects of each factor could be analyzed separately.

The systems chosen for our purpose were 2 different solar salterns. These consist of a series of shallow ponds connected in a sequence of increasingly saline brines, used for the commercial production of salt from seawater. During evaporation of seawater, sequential precipitation of calcium carbonate, calcium sulfate and finally sodium chloride occurs. As the salinity increases, the multiple connections in the microbial loop decrease. The increase in salinity results in a gradual disappearance of large forms of life and marine prokaryotes at salinities lower than $100 \%$. From this salinity up to $200 \%$ prokaryotic assemblages are dominated by moderately halophilic organisms. From $200 \%$ salinity on wards changes affecting the microbial populations can be followed by the changes in the aspect of the water the green-brown color of the water changes to red in the crystallizer ponds. Such ponds become almost monospecific cultures of halophilic archaea (Rodriguez-Valera 1988). The different ponds in the salterns are maintained under constant conditions over long periods of time, enabling the microbial populations to reach an equilibrium at each pond (Rodríguez-Valera 1988, C. Pedrós-Alió, J. J. Calderón-
Paz \& M. Maclean unpubl.). This common feature among salterns allowed us to assume that the microbial populations living in them were in a steady state.

We quantified the distribution of virus-like particlcs (VLP), the frequency of infected celis and the burst size throughout the salinity gradient. Using conversion factors from the literature (Proctor et al. 1993), we estimated prokaryotic mortality due to viral lysis and the production rate of viruses. Prokaryotic heterotrophic activity and bacterivory were measured to compare the 2 sources of mortality (due to viruses and to bacterivores).

The finding of high abundance of 'square archaea' and the fact that these were the only visibly infected cells in the saltiest ponds allowed a study of them to be made separately from the rest of the prokaryotic community.

We demonstrate that viruses have a small effect in controlling the whole prokaryotic abundance under steady state and that their influence on prokaryotic growth rates is minimal in these systems.

\section{MATERIALS AND METHODS}

Terminology. In order to be consistent with the currently accepted terminology for the prokaryotes we have used the term 'prokaryote' when referring to all the community of prokaryotes and the term 'archaea' when referring to this particular domain (Woese et al. 1990). The problem arises when referring to 'grazing' or 'bacterivory' since neither one is appropriate to refer to predation on prokaryotes including a mixture of bacteria and archaea. In order to avoid cumbersome terms, however, we have retained the words bacterivore and bacterivory when referring to predation on prokaryotes. For the 'square cells' we have used the term 'square archaea', because it is accepted that they belong in the archaeal domain (Stoeckenius 1981).

Solar salterns. Samples were collected on 28-29 July 1994 from the multi-pond solar saltern 'La Trinitat' located in Delta de l'Ebre (Tarragona, Spain, 40 35' $\mathrm{N}$, $0^{\circ} 41^{\prime} E$ ). The water salinity of the 9 ponds sampled represented the increasing gradient from seawater salinity $(37 \%)$ to the crystallizers $(370 \%)$. The ponds are shallow, about $0.5 \mathrm{~m}$ deep, and their area varies from 200 ha tor the less saline to jusi 3 ild in the crystallizers. A very persistent breeze keeps the water well mixed. Samples were taken with a bucket at the end of a pole, collecting mostly subsurface water. The corners of the square ponds were avoided, since the wind accumulates organic matter scums and debris in those areas. Some data were also collected in the 'Braç del Port' salterns (Santa Pola, Alacant, Spain, $38^{\circ} 12^{\prime} \mathrm{N}$, $0^{\circ} 36^{\prime} \mathrm{W}$ ) on 29-31 July 1993 . The range of salinities in the latter was from 38 to $382 \%$. 
Abundance of prokaryotic cells and viruses. In each pond, 3 samples of $25 \mathrm{ml}$ were collected in polypropylene bottles and fixed immediately with formaldehyde (4\% final concentration). Viral and prokaryotic abundances were determined using ultracentrifugation and transmission electron microscopy (TEM; Børsheim et al. 1990). To avoid interference of the high prokaryotic numbers in viral counts, we diluted the samples 4 times at salinities lower than $250 \%$ and 10 times at higher salinities. The dilution was done with distilled water filtered through an Anopore filter (pore size $0.02 \mu \mathrm{m}$ ). Previously, we had checked that both cells and VLP remained intact after dilution.

Cells and viruses were harvested onto the grids (400mesh Ni electron microscope grids with carbon coated formvar film) using a Beckman SW41 swing-out rotor run at $40000 \mathrm{rpm}$ for $30 \mathrm{~min}$ at $20^{\circ} \mathrm{C}$ (Bratbak \& Heldal 1993, Suttle 1993). For each sample, duplicate grids were stained for 1 min with uranyl acetate $(2 \% \mathrm{w} / \mathrm{w})$. VLP were enumerated and sized in a Jeol $100 \mathrm{CX}$ transmission electron microscope operated at $80 \mathrm{kV}$ and at a magnification of $100000 \times$. Fields were randomly selected and counted until the total counts exceeded 200 VLP. Prokaryotic cells were enumerated in the same preparations at $20000 \times$ magnification. Viral abundance was also determined using DAPI stain and counting the particles under the epifluorescence microscope (Suttle 1993). We used epifluorescence in order to compare viral counts between 2 different salterns, since this technique is much faster for routine use.

Frequency of cells containing mature phages. Because of the high acceleration voltage $(80 \mathrm{kV})$ used in this study, we were able to identify cells containing mature phages (Heldal \& Bratbak 1991). A cell was considered as infected when phages inside could be clearly recognized on the basis of shape and size (Bratbak et al. 1992, Weinbauer et al. 1993). The minimal number of phages found in an infected cell was 6 . At least 200 fields at $20000 \times$ magnification were inspected for potential infection in each sample. The number of mature phages inside cells gave an estimation of the burst size (Weinbauer et al. 1993).

Because of the low abundance of infected cells in all the samples we did not calculate the frequency of cells with mature phages separately for each morphotype, except in the case of the infected square archaea at salinities higher than $180 \%$, where this morphotype became more abundant.

Prokaryotic heterotrophic activity. Prokaryotic heterotrophic activity was measured through the incorporation of [methyl- ${ }^{3} \mathrm{H}$ ] thymidine (TdR; Bell 1993). Samples of $10 \mathrm{ml}$ were incubated in the dark at in situ temperature for $45 \mathrm{~min}$ with $20 \mathrm{nM} \mathrm{TdR}$. Two repli- cates plus a formaldehyde killed control were incubated for each pond. To end the incubation, formaldehyde was added and the vials kept in a cooler with ice until return to the laboratory. The samples were filtered and counted in a liquid scintillation counter (Pedrós-Alió et al. unpubl.).

Bacterivory. Bacterivory by protists was measured with fluorescently labeled bacteria (FLB; Sherr et al. 1987), using the FLB disappearance method (Pace et al. 1990, Salat \& Marrasé 1994). FLB were prepared from a heterotrophic bacterium isolated from the Mediterranean coast $(1 \times 0.8 \mu \mathrm{m}$, biovolume $0.42 \mu^{3}$ ). This cell size is a compromise between the average cell volume at the lowest salinity ponds $\left(0.084 \mu^{3}\right)$ and at the highest salinity where bacterivory was measured $\left(0.916 \mu^{3}\right)$. Bacterivory experiments were carried out in all ponds except for the 2 crystallizers (with salinities > 300\%). At these high salinities no predators were present, since neither flagellates nor ciliates can live in the crystallizers. Samples (1 1) were incubated at in situ temperature in polycarbonate bottles in the dark. Two replicates and a control killed with formaldehyde (final concentration 1\%) were carried out at each pond. Incubations lasted $48 \mathrm{~h}$ and were stopped by fixing subsamples with glutaraldehyde (final concentration $2 \%$ ).

\section{RESULTS}

\section{Abundance of prokaryotic cells and VLP}

Total counts of prokaryotes increased with salinity by 1 order of magnitude from the less saline pond $(37.5 \%)$ up to the most saline (370\%; Fig. 1A). Abundance of VLP increased by almost 2 orders of magnitude in the same range of salinities (Fig. 1A). Prokaryotic and VLP abundance were significantly correlated $(p<0.001, r=0.97, n=9)$ (Fig. 1B).

Because of their particular shape, size and abundance at salinities higher than $250 \%$, it was possible to quantify square archaea separately (Table 1). In order to avoid possible confusion with odd-shaped prokaryotes that could occasionally appear square in the harvested samples, we used the criterion of Stoeckenius (1981) to classify them: square archaea were identified as flat and rectangular cells with perfectly straight edges, measuring a few $\mu \mathrm{m}$ on the side (Fig. 2A). The smallest cells were square, measuring $2 \times 2 \mu \mathrm{m}$, whereas the largest cells were often rectangular with mean side lengths of $1.87 \pm 0.56$ and $2.83 \pm 0.53 \mu \mathrm{m}$. In the saltiest ponds the square archaea constituted around $25 \%$ of the total number of prokaryotes (Table 1). 

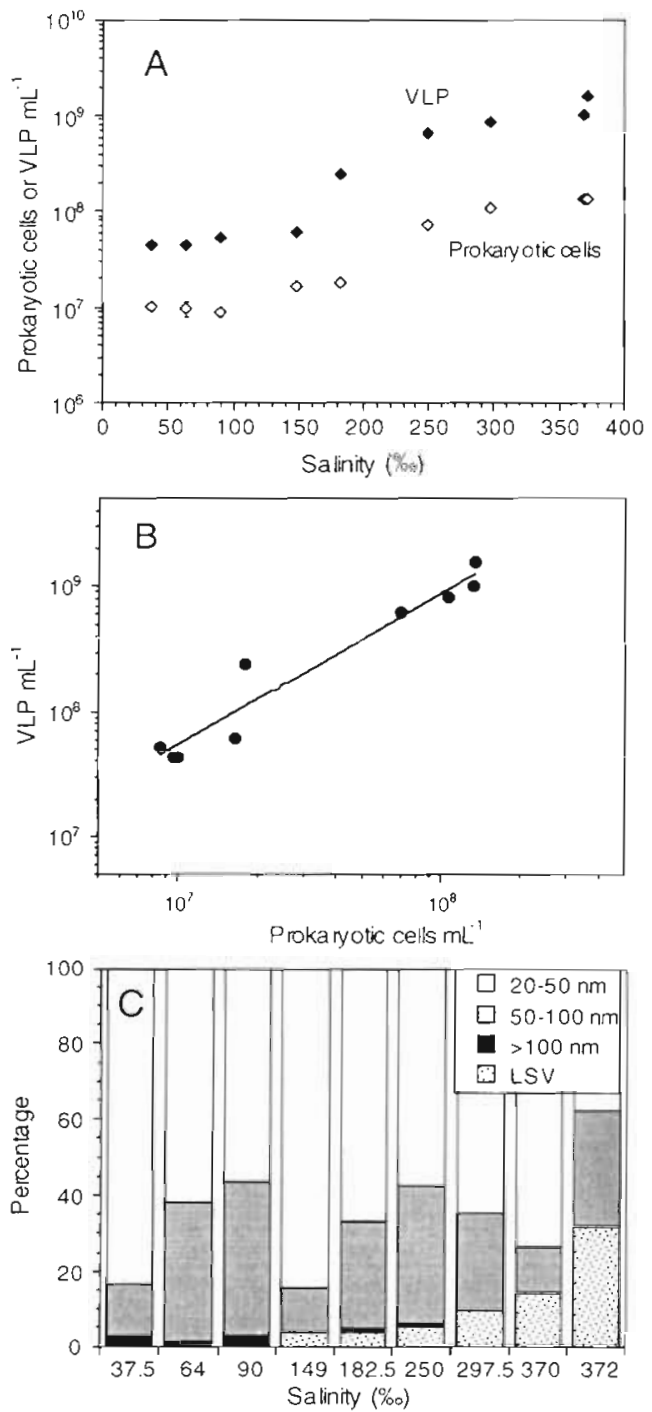

Fig. 1 (A) Prokaryotic and viral abundance along the salinity gradient. Bars indicate standard errors based on 2 replicates. When no bars are visible, errors are smaller than marker points. (B) Relationship between prokaryotic and viral abundance. (C) Viral size class distribution represented as percentage of the total in each pond. LSV: lemon-shaped viruses

\section{Size distribution of viruses}

VLP were classified into 4 classes based on shape and the diameter of their heads (Figs. IC \& 2E, F). Most VLP in all ponds had icosahedral heads of 20 to $50 \mathrm{~nm}$. The percentage of VLP in each class did not follow any pattern with increasing salinity, except for the lemon-shaped viruses (LSV; Fig. 2E, F). These LSV showed a progressive increase in abundance with increasing salinity, reaching $31.4 \%$ of the VLP in the most salt concentrated ponds. The size of these viruses, apparently untailed, was $40 \times 80 \mathrm{~nm}$. The abundance of LSV was significantly correlated with that of square archaea ( $\rho<0.03, r=0.7, n=9$ ). These viruses were seen infecting square archaea, but the number of inferted cells was too low for statistically significant counts. Thus, we could not provide infection percentages for LSV-square archaed separately. The squarc archaea, however, were often infected by viruses with other morphologies (Fig. 2C).

\section{Prokaryotic heterotrophic activity and bacterivory}

Thymidine incorporation (Fig. 3A) did not show a clear pattern with salinity increase or with VLP numbers. The activity per cell showed the highest values at salinities lower than 170\% (Fig. 3A). Data on thymidine incorporation rates, combined with the abundance of prokaryotes, enabled calculations of prokaryotic doubling times, using a theoretical conversion factor of $1.5 \times 10^{18}$ cell $\mathrm{mol}^{-1} \mathrm{TdR}$ (Pedrós-Alió et al. unpubl.). Doubling times became higher than $2 \mathrm{~d}$ at salinities higher than $170 \%$ (Fig. 3B),

Bacterivory (ingested prokaryotes $\mathrm{ml}^{-1} \mathrm{~d}^{-1}$ ) showed the highest values in ponds with salinities between 78 and $150 \%$ (Fig. $3 \mathrm{C}$ ). In the 2 more concentrated ponds where bacterivory was measured we did not find any

Table 1. Frequency of bacteria containing mature phages and relative abundance of square archaea. Values are means calculated from the 2 grids observed from each pond. Range of values shown in parentheses. NP: not present

\begin{tabular}{|c|c|c|c|c|}
\hline Sait puinu & 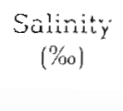 & $\begin{array}{c}\text { Bacteria with } \\
\text { mature phages } \\
\text { (\% of total) }\end{array}$ & $\begin{array}{c}\text { Sorlare archaea } \\
(\% \text { of total bacteria) }\end{array}$ & $\begin{array}{c}\text { Square archaea } \\
\text { with mature phages } \\
\text { (\% of square archaea) }\end{array}$ \\
\hline TR1 & 37.5 & $<0.04$ & 0 & NP \\
\hline TR2 & 64 & $<0.05$ & $<3$ & NP \\
\hline TR3 & 90 & $<0.06$ & $<3$ & NP \\
\hline TR7 & 149 & $1.28(0.35-2.21)$ & $<5$ & NP \\
\hline TR5 & 182.5 & $1.30(0.26-2.33)$ & $<5$ & NP \\
\hline TR4 & 250 & $1.88(0.00-3.76)$ & $8.53(8-8.9)$ & $1.57(1.19-1.95)$ \\
\hline TR6 & 297.5 & $0.85(0.51-1.20)$ & $31.51(28-34)$ & $2.81(1.67-3.94)$ \\
\hline TR8 & 370 & $1.30(0.86-2.71)$ & $28.09(15-40\}$ & $6.73(3.26-10.2)$ \\
\hline TR9 & 372 & $0.62(0.50-0.74)$ & $21.78(17-30)$ & $2.57(2.08-3.07\}$ \\
\hline
\end{tabular}




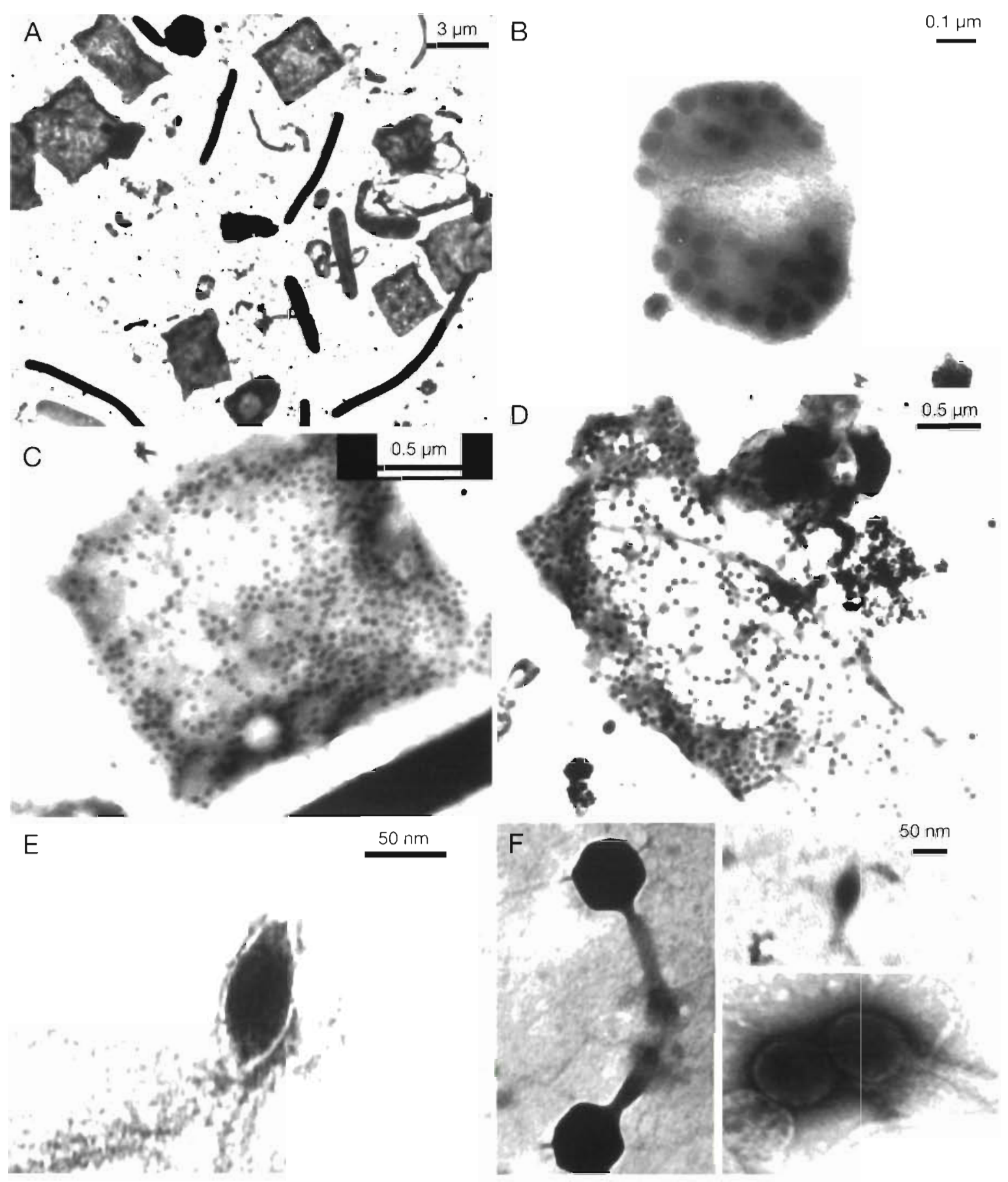

Fig. 2. (A) Prokaryotic cells in the crystallizer ponds (370\% salinity), the sample was diluted 10 times (see 'Materials and methods'). (B) Prokaryotic cell with phage particles, head diameter ca $60 \mathrm{~nm}$. (C) Square archaea with phage particles, head diameter ca $40 \mathrm{~nm}$. (D) Square archaea lysed by phages, head diameter ca $50 \mathrm{~nm}$. (E) Lemon-shaped virus. (F) Different types of phages, including 2 icosahedral, tailed types and a lemon-shaped virus

disappearance of FLB. Prokaryotic heterotrophic activity ( $\mathrm{pmol} T \mathrm{dR}^{-1} \mathrm{~h}^{-1}$ ) was significantly correlated with bacterivory ( $\mathrm{p}<0.001, \mathrm{r}=0.866, \mathrm{n}=10$ ) and, conversely, doubling times were longer when bacterivory was lowest.

\section{Frequency of infected prokaryotes and burst size}

In the ponds with total salinity values lower than $150 \%$ we did not find any infected cells in 200 fields screened for each grid, with an average of 10 cells per 

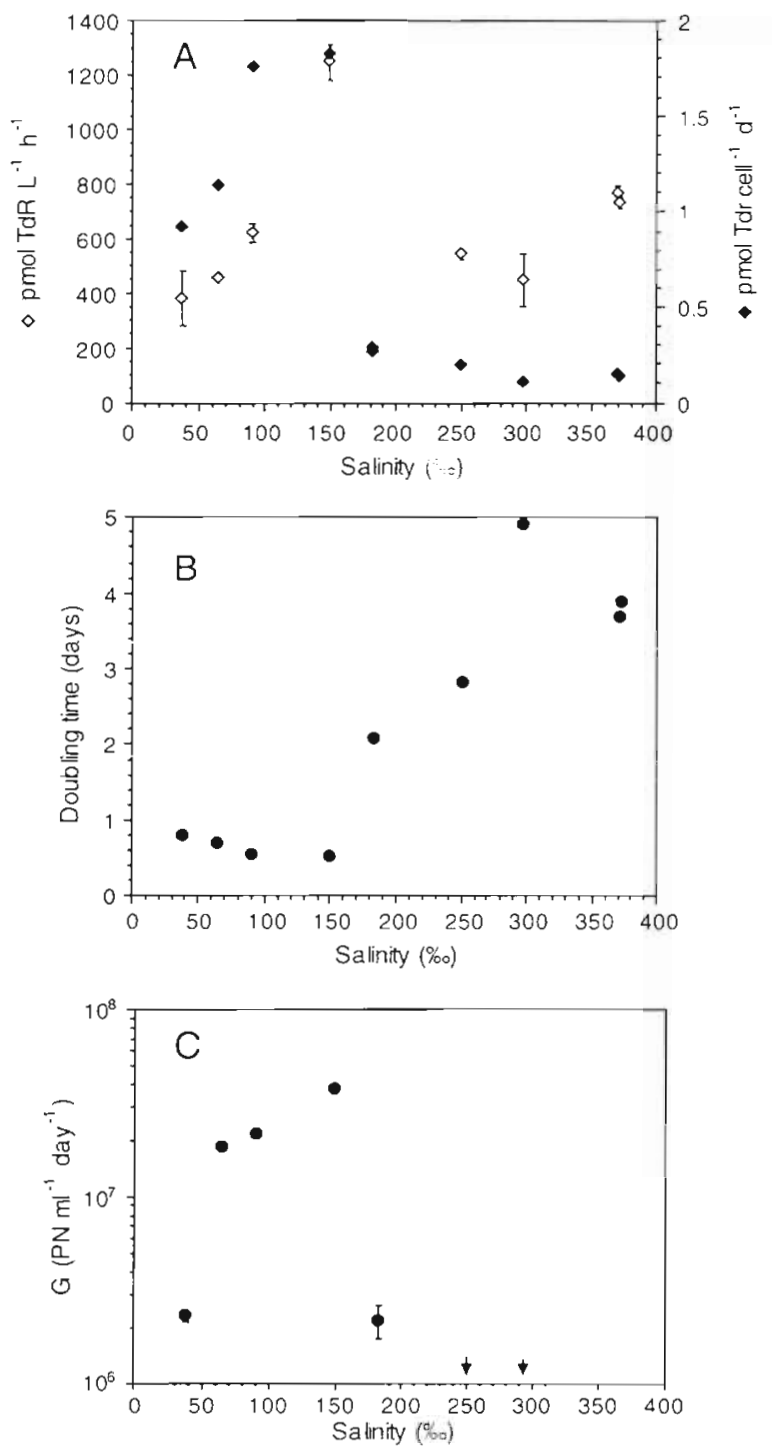

Fig. 3. (A) Incorporation of [methyl $-{ }^{3} \mathrm{H} \mid$ thymidine $(\mathrm{TdR})$ along the salinity gradient $(\diamond)$ and $T d R$ incorporation per cell $(\bullet)$. Bars indicate standard errors based on 2 replicates. When no bars are visible, errors are smaller than marker points. (B) Doubling times of the prokaryotic assemblage in each pond. (C) Prokaryotes ( $P N$ ) ingested by bacterivores along the salinity gradient. Bars represent standard errors of 2 replicates. Arrows indicate ponds where bacterivory was found to be zero

field. In the ponds with higher salinities the overall frequency of prokaryotes visibly infected with phages ranged between 0 and $3.76 \%$ (Table 1). No significant differences were found among the different ponds (ANOVA, $\mathrm{p}>0.05, \mathrm{n}=12$ ). The frequency of infected cells for the square archaea ranged between 1.19 and $10.2 \%$, showing the highest values in pond TR8 (Table 1). Again, among the ponds where these archaea were present, differences were not significant
(ANOVA, $p>0.05, n=8$ ). In the ponds with salinities higher than $350 \%$ (TR8 and TR9) all the infected prokaryotes that we could see belonged to this morphotype. The LSV were secn infecting only square archaea.

The number of viruses inside the infected prokaryotes (square archaea excluded; Fig. 2B) ranged between 6 and 35 phages per host cell (mean $22 \pm 7$ ). The number of phages found in the infected square archaea (Fig. 2C, D) was significantly different (Student's $t$-test, $\mathrm{p}<0.001)$ from that in other infected prokaryotes, ranging between 100 and 380 (mean $203 \pm 77$ ). We did not find differences in burst size for the same morphotype among the ponds.

\section{Losses of prokaryotic abundance and production}

In order to estimate the impact of viral attack on the prokaryotic assemblages we had to use a series of assumptions. In the first place, we calculated the total number of infected prokaryotes (TIP) from the number of visibly infected prokaryotes (VIP) and the range of conversion factors ( $f: 3.7$ to 7.14 ) provided by Proctor et al. (1993): TIP $=$ VIP $\times f$. We then reasoned that this number of infected cells is the number of cells that would die within a time equivalent to the latent period $(L)$ of the phage infection. Thus, the prokaryotes lysed per $\mathrm{ml}$ per day because of viral infection $(v)$ is: $V=$ TIP/L.

The latent period $L$, however, is unknown for a natural assemblage which may combine several phageprokaryote systems. An approach used by Proctor et al. (1993) was based on the similitude between $L$ and the doubling times $(D t)$ of the host-prokaryotic systems. Under this assumption $L=D t$ and thus:

$$
V=\operatorname{TIP} / D t=(\mathrm{VIP} \times f) / D t
$$

The results of these calculations are shown in Fig. 4A. It is apparent that despite very different doubling times (Fig. 3B) in the ponds where viral infection was measurable, the number of prokaryotes lysed per $\mathrm{ml}$ and per day was fairly similar throughout the salinity gradient.

From the number of prokaryotes lysed per day and the bus sice of the infected prokaryotcs we could ca! culate the number of viruses produced per day. The number of viruses produced markedly increased with salinity (Fig. 4A), due to the larger burst size of the prokaryotes in the most saline ponds.

The importance of viruses and bacterivores in controlling prokaryotic abundance and production is shown in Fig. 4B. The percentage of prokaryotic losses attributed to viral lysis was always lower than $20 \%$ of both biomass and production. Bacterivory, on the other 

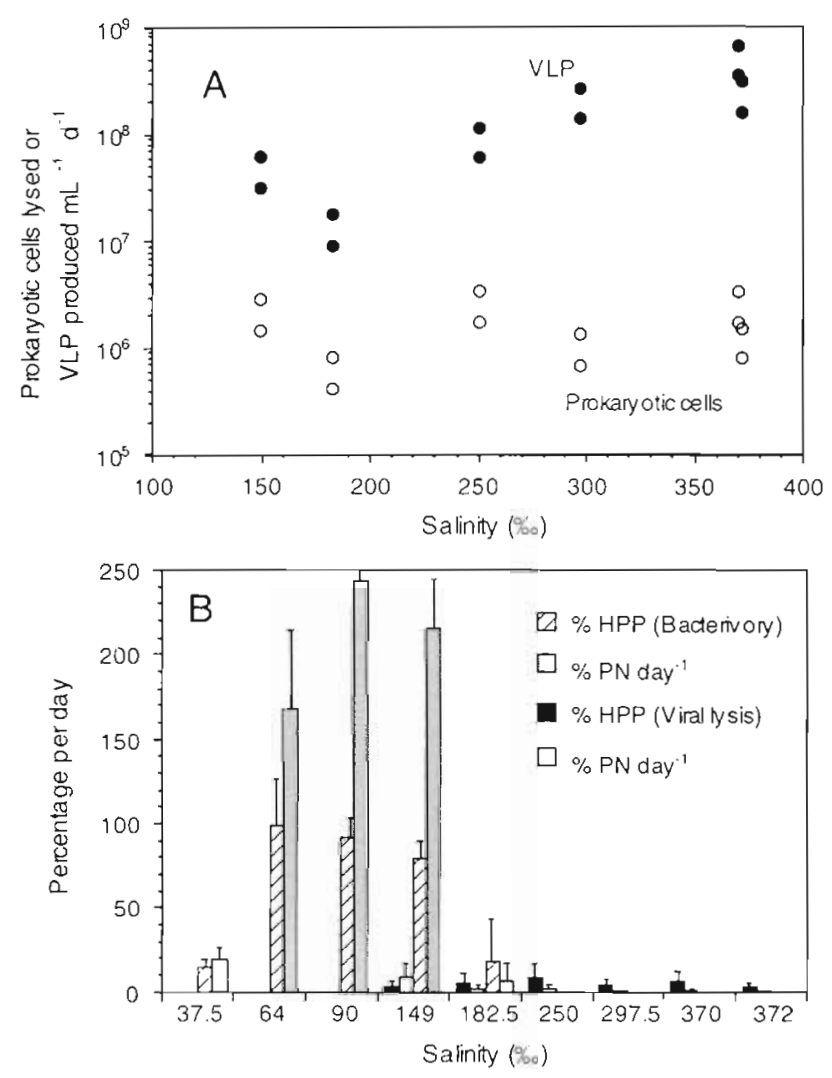

Fig. 4. (A) Prokaryotic lysis rates and viral production rates along the salinity gradient. The 2 points for each salinity represent the values found after applying the range of conversion factors (Proctor et al. 1993) to the average percentage of visibly infected cells (Table 1). (B) Percentage of heterotrophic prokaryotic production (HPP) and abundance (PN) ingested by bacterivores and lysed by viruses per day in the different ponds. Error bars (only the upper one shown) indicate the lowest and the highest calculated values

hand, accounted for a much higher fraction of prokaryotic abundance and production losses at salinities lower than $180 \%$. In the first pond, with a salinity similar to that of seawater, both the percentages of prokaryotic abundance and production ingested by bacterivores were lower than $30 \%$. In the ponds with salinities ranging from 64 to $150 \%$, bacterivory accounted for about $100 \%$ of the prokaryotic production. This represented more than $100 \%$ of the prokaryotic abundance per day, due to the fact that prokaryotes in these ponds doubled approximately twice a day. Viral infection could be first detected at $150 \%$ salinity. At this salinity, both the percentage of bacterial abundance and production losses attributed to viral lysis were almost 30 times lower than the percentage attributed to bacterivory. At $182 \%$ salinity, viral lysis and bacterivory reached similar low percentages, although bacterivory was still 3 times higher than viral lysis. At this salinity, prokaryotic doubling times (Fig. 3B) increased about 2 -fold with respect to doubling times at lower salinities.

From $250 \%$ salinity onwards, bacterivory disappeared and viral infection acted alone. The percentage of prokaryotic abundance losses per day attributed to viral lysis was lower than $5 \%$. At the saltiest ponds (from 250 to $372 \%$ salinity), prokaryotic doubling times reached values ranging between 2.5 and $5 \mathrm{~d}$ (Fig. 3B).

\section{Comparison between salterns}

Salterns derived from seawater have the same types of salts in solution all over the world. Due to this characteristic, organisms and ecological relationships among different salterns are similar (Rodriguez-Valera 1988, Oren 1994). In order to confirm this similarity for the viruses we compared prokaryotic and viral abundance between La Trinitat and Braç del Port salterns, located in different places along the Mediterranean coast (Fig. 5). In Braç del Port bacterial and viral abundance were determined using DAPI stain and epifluorescence microscopy. In order to compare both salterns, we also determined viral abundance in $\mathrm{La}$ Trinitat with epifluorescence microscopy. Although in La Trinitat salterns the viral abundance determined with epifluorescence microscopy (Fig. 5B) was 2 to 20 times lower than that found with TEM (Fig. 1A), viral counts done with DAPI were highly reproducible. From 6 replicate filters for each pond from Braç del Port, the percentage of variability around the mean was always lower than $10 \%$. Thus, despite the lower sensitivity of DAPI-epifluorescence microscopy with respect to TEM to estimate viral abundance, the method should be useful to compare different samples with similar physico-chemical characteristics.

Prokaryotic abundance in the 2 salterns showed a similar pattern (Fig. 5A). The abundance was lower than $4 \times 10^{7}$ prokaryotic cells $\mathrm{ml}^{-1}$ at salinities lower than $200 \%$ and increased up to $1 \times 10^{8}$ prokaryotic cells $\mathrm{ml}^{-1}$ from this salinity on. Square archaea started to be considerably abundant at $250 \%$ salinity in both salterns (Fig. 5A). Viruses also followed a similar pattern in both salterns and reached maximal abundance at salinities higher than $250 \%$ (Fig. 5B).

\section{DISCUSSION}

\section{Advantages of solar salterns for the study of virus-prokaryote interactions}

The solar salterns provide a range of environments specially suited to test hypotheses in microbial ecology. Limited species diversity, high cell abundance 

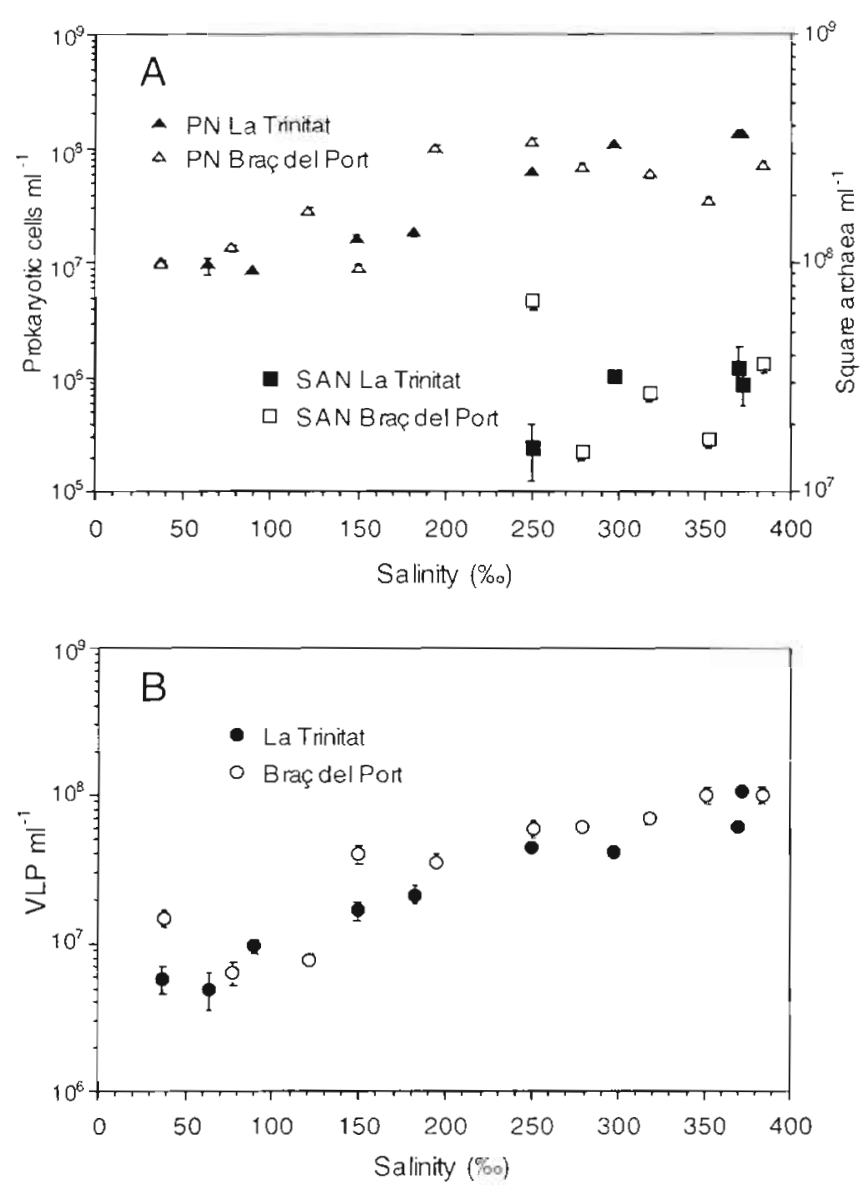

Fig. 5. (A) Abundance of prokaryotes (PN) and square archaea (SAN) along the salinity gradient from 2 salterns (Braç del Port and La Trinitat). Bars represent standard errors of 2 replicates. (B) Viral abundance from the 2 salterns, determined with DAPI stain and epifluorescence microscopy. Bars represent standard errors of 6 replicates in Braç del Port and of 2 replicates in La Trinitat. When no bars are visible, errors are smaller than marker points

and short food chains (Rodríguez-Valera 1988, Oren 1994) make the system progressively simple and easy to analyze. The gradient of salinity, from seawater to saturated sodium chloride brines, allows examination of microbial processes as more and more components disappear as their upper tolerance limit to salt is reached One lact advantage of this system is that each pond can be considered to be at steady state. Cell abundance does not change in different years (PedrósAlio et al. unpubl.) and, except for the rare heavy rainfalls, there are essentially no alterations of the system. This allowed simultaneous calculation of the total mortality due to bacterivory and viruses.

We also knew that bacterivory would decrease and finally disappear as salinity increased (Pedrós-Alió et al. unpubl.), while viral lysis could potentially be present throughout the gradient. Therefore, we could check whether viral mortality and bacterivory covaried, varied in opposite directions or did not show any relationship to each other. Finally, these ecosystems are markedly similar all over the world, in as far as they are derived from the evaporation of seawater, and the conclusions drawn from the study of specific salterns should have a more general validity (Oren 1994)

\section{Abundance of VLP and percentage of infected cells}

The numbers of VLP found in the salt ponds $\left(10^{7}\right.$ to $10^{9} \mathrm{ml}^{-1}$ ) are some of the highest reported in planktonic systems (Fuhrman \& Suttle 1993, Maranger \& Bird 1995). The variability in viral abundance among the ponds was largely explained by the abundance of prokaryotic cells (PN). Several studies have reported that the strength of the VLP/PN rclationship found, indirectly suggested that the majority of viruses in these environments were of prokaryotes (Proctor \& Fuhrman 1990, Cochlan et al. 1993, Maranger \& Bird 1995). Our data support this idea, since VILP numbers were significantly correlated with prokaryotic abundance but no correlation was found between VLP and chlorophyll a concentrations (data not shown).

In one study it was also suggested that there is a correlation between cell abundance and frequency of cells containing mature phages (Weinbauer et al. 1993), but in another study this correlation was not found (Steward et al. 1996). From our data, the percentage of infected cells was not different among the ponds. However, the production of viruses increased with prokaryotic cell abundance due to the different burst sizes of the prokaryotes in the different ponds. A large variability in the burst size of whole marine bacterial assemblages (10 to 300) has been reported in other studies (Heldal \& Bratbak 1991, Steward et al. 1996). Considerable variability in the burst size of different bacterial morphotypes has been found (Weinbauer \& Peduzzi 1994). Other factors such as growth rate or cell volume could also influence the burst size of the prokaryotes

Phage production rates may be used to calculate phage-induced bacterial mortality when the burst size is known. Some studies have used the minimum (10), the maximum (300) and the average (50) burst sizes reported for marine environments (Steward et al. 1992). The range of prokaryotic mortality rates reported in this way change by an order of magnitude, depending on the assumed burst sizes. These studies have advised caution about the uncertainty of their mortality estimates (Steward et al, 1992). Our data are a clear example of the importance of determining the burst size of the prokaryotes in each environment in 
order to obtain accurate estimates of bacterial mortality due to viral lysis, when the latter are estimated from phage production rates. Despite some uncertainties in the determination of burst sizes with current methods (Weinbauer \& Peduzzi 1994), this is the most direct way available to estimate viral mortality.

We calculated viral production from direct measurement of burst sizes and number of infected cells. The viral production in the different ponds was within the range of values reported for other environments (Steward et al. 1992). Assuming that the ponds are at steady state, the VLP number should not change with time. Thus, our estimated virus production rates should be equal to decay rates. These rates varied between 0.04 and $0.7 \mathrm{~h}^{-1}$, which also fall within the range of published values (Heldal \& Bratbak 1991, Bratbak et al. 1992, Mathias et al. 1995).

We conclude that it is possible to support a high phage production rate with low percentages of prokaryotic mortality in nature. The low percentage of prokaryotic mortality due to viral infection and the high bacterial biomass suggest that viruses do not control total prokaryotic abundance.

\section{Prokaryotic mortality: virus infection versus bacterivory}

The factors that control growth rate and mortality of prokaryotes in aquatic environments have received considerable attention. However, very few studies have included direct measurements of viral lysis. In one study losses due to bacterivory and viral lysis were determined simultaneously in a mesocosm (Bratbak et al. 1992). These authors measured primary production, bacterial production, viral decay rates and bacterivory. In their results, predation exceeded bacterial production estimates by a factor of 2. Viral lysis exceeded bacterial production by a factor of 6 . Therefore, a balance could not be found. Fuhrman \& Noble (1995) found a balanced budget between bacterial losses and production including bacterivory and viral infection. They used independent lines of evidence to conclude that viruses and protists caused comparable rates of bacterial mortality in 2 mesocosm experiments. Recently, Steward et al. (1996) reported comparable rates of bacterial mortality due to viral lysis and flagellate bacterivory in Arctic waters. They did not find a balance between bacterial production and these 2 sources of bacterial mortality, suggesting that other sources of bacterial mortality were present.

We have quantified the 2 factors that have been reported to account for most of prokaryotic mortality in nature. Taking advantage of the steady state dynamics present in the salterns, we could assume a balance between prokaryotic heterotrophic production and losses due to bacterivory and viral lysis. In our study, prokaryotic production balanced prokaryotic losses in 3 of the ponds where bacterivory was present from 64 to $149 \%$ salinity). In the other 2 ponds ( 37.5 and $182.5^{\circ}$ w salinity) prokaryotic production was 2 to 4 times higher than prokaryotic losses. In the higher salinity ponds, bacterial production exceeded losses by viral infection by a factor $>10$. Since production was higher than the measured losses in the higher salinity ponds, there must exist other sources of mortality, perhaps flocculation and sedimentation. Some characteristics of the halophilic archaea, such as the production of sall-requiring bacteriocins that inhibit the growth of other halophilic archaea, have been reported as a source of mortality in laboratory cultures (Oren 1994).

Moreover, special characteristics of several halophage-halophilic archaea systems, such as carrierstates, could also contribute to explain this uncoupling. A carrier state has been defined as a situation in which the host, persistently carrying and continually producing viruses, survives and multiplies (Pauling 1982, Zillig et al. 1988). In this carrier state, infected bacteria continue to multiply at the same rate as uninfected bacteria (Torsvik \& Dundas 1980). Thus, infected cells could produce phages without increasing mortality.

We do not know the relative importance of these different processes (flocculation, sedimentation, presence of bacteriocins and establishment of carrier states). Studies in the laboratory suggest that they could be potentially important in the salterns. The fact that prokaryotic heterotrophic production exceeded losses by viral infection in the saltiest ponds supports this hypothesis. Another possible explanation could be an underestimation of viral lysis. This is discussed in a later section.

\section{Prokaryotic growth rate and viral lysis}

There is evidence that the supply of organic matter may control bacterial growth in many aquatic environments (Billen et al. 1990). It is also known that bacterivores are important contributors to the dissolved organic matter pools in the oceans (Taylor et al. 1985 , Nagata \& Kirchman 1992). This recycling of nutrients increases prokaryotic growth rates in the presence of bacterivores. A similar effect has been suggested for viral lysis of bacteria (Fuhrman \& Suttle 1993, Weinbauer \& Peduzzi 1995b). From our results, the doubling times of prokaryotes were longer in the ponds where bacterivory was absent and viral lysis acted alone, and shorter in ponds where both bacterivory and viral lysis were present. Thus, we can conclude that viruses had an effect smaller than bacterivores in increasing 
prokaryotic growth rates. However, viral lysis may play a significant role in maintaining moderate prokaryotic growth rates in the saltiest ponds.

Hypersaline environments are of ten rich in nutrients, and in the salterns the temperature is close to the optimal for growth of halophilic prokaryotes (Oren 1994). Other requirements, such as ionic composition of the ponds, could determine the growth rate of the different prokaryotic assemblages. Therefore, the growth stimulation due to bacterivores and viruses may be partially masked by these other factors.

\section{Critical assumptions in the calculation of bacterial mortality}

We estimated bacterial mortality caused by 2 different factors: bacterivory and viral lysis. Both estimates are subject to errors. If the errors were very high, some of the conclusions would be invalid. The FLB technique to determine bacterivory has been used many times in different environments and is usually taken to give reasonable estimates (Sherr et al. 1989). In our case the use of a single bacterial culture to prepare FLB which were then used in all ponds may have introduced some error. The FLB were larger than average prokaryotic volume in the lower salinity ponds and smaller than the average in the higher salinity ponds (see 'Materials and methods'). Bacterivores are known to feed preferentially on larger bacteria, as long as they fall within a certain size range. Thus, our bacterivory estimates could be overestimates at lower salinities and underestimates at higher salinities. We think, however, that this was not a major problem. According to this line of reasoning the $37 \%$ salinity pond should have shown the highest overestimation, yet grazing in this pond was relatively low. In fact, it showed the same value as in the $180 \%$ salinity pond, where average bacterial volume was similar to that of the FLB. Thus, factors other than size were having a much stronger impact on predation estimates. Further, grazing estimates were very reasonable in all cases. They showed a covariation with bacterial specific thymidine incorporation rates and decreased down to zero as salinity increased in parallel to the abundance of ciliates and flagellates. Thus, we conclude that the large differences in grazing between ponds are real, even if the absolute value is subject to some error.

The critical assumptions used to calculate viral mortality from visibly infected cells by TEM are: the ultracentrifugation step, the conversion factors to convert visibly infected cells to total number of infected cells, and the assumption that the latent periods are similar in length to the host doubling times.
During the ultracentrifugation process there is the possibility that we lost phage-infected prokaryotes by disruption of cells (Weinbauer \& Peduzzi 1994). Thus, the frequency of infected cells reported would tend to be conservative.

The conversion factor used to obtain the total number of infected cells was derived from thin sections (Proctor et al. 1993), and we applied it to samples observed directly by negative staining. The total number of cells with mature phages may be higher than the visibly infected cells but perhaps not in the same proportion as in thin sections (Fuhrman \& Suttle 1993). Fuhrman \& Noble (1995) used both methods to estimate the percentage of infected cells. Although they only had 2 measurements to compare both methods, the number of visibly infected cells found with thin sections was higher than that counted with direct observations of infected bacteria. Thus, our estimates of infection for the whole prokaryotic community could be considered conservative (but not those for the square archaea). The special morphology of this group (flat and square) made it possible to avoid some of the inconveniences of the direct observation of infected cells (variation in staining and cell thickness; Fuhrman \& Noble 1995). Moreover, the conversion factor derived using the whole cell method in natural communities (M. Weinbauer, cited in Steward et al. 1996) was within the range calculated by Proctor et al. (1993).

The most critical step in our calculations is the assumed equivalence between the generation times of the prokaryotes and the latent periods of the viruses. To test this assumption, Proctor et al. (1993) compared latent periods and generation times of marine isolates cultured with a range of nutrients. We have added data from the few studies done with halotolerant and halophilic prokaryotes and their phages in a range of salinities, to their data set (Fig 6). The regression with the added data was significant $\left(\mathrm{r}^{2}=0.68, \mathrm{p}<0.001, \mathrm{n}=\right.$ 42 ), and the slope of the regression was not significantly different from 1 (Student $t$-test, $p>0.05$ ). Therefore, it seems safe to assume similar lengths for the latent periods and the generation times.

Another possible error in our calculations is the assumption that all the infected prokaryotes will lyse during the tume of the iatent period. Ii ilds beêi sugygested that it is possible that bacterivores ingest infected bacteria, even at a higher rate than noninfected bacteria (Weinbauer \& Peduzzi 1995b). This could be the reason why we did not find any visibly infected cells in the lower salinity ponds. If this were the case, our data of mortality due to viral lysis would be still lower in the ponds where the bacterivory was present. This would not matter, however, in the ponds with higher salinities, where bacterivory was zero. 


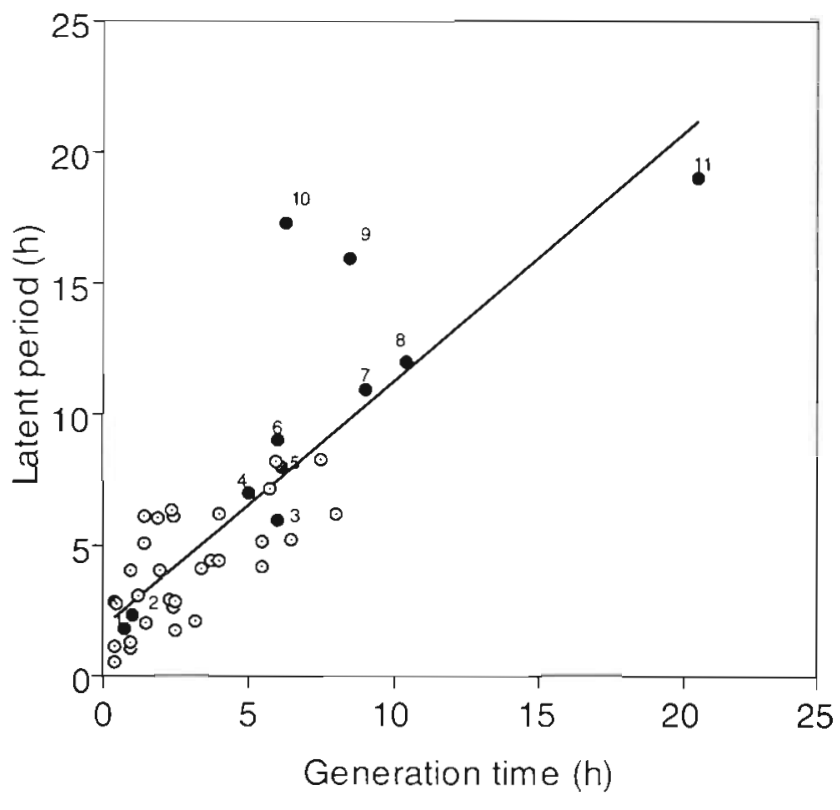

Fig. 6. Generation time of uninfected cells versus latent period of infected hosts. (०) Data from Proctor et al. (1993). (•) Data from the halotolerant/halophilic prokaryote-phage systems reported in the literature: $(1,2)$ Deleya halophila/F19 from Calvo et al. (1988); (3) Halobacterium halobium/Ja1 from Wais et al. (1975); (4) Halobacterium halobium str. R1/ $\$ \mathrm{H}$ from Schnabel et al. $(1982) ;(5,8)$ Halobacterium halobium/ Hh3, Hh1 from Pauling $(1982) ;(6,7)$ Halobacterium cutirubrum NRC 34001/S5100 from Daniels \& Wais (1990); (9 to 11) Halobacterium salinarium/HS1 from Torsvik \& Dundas (1980)

We cannot give the quantitative importance of these sources of error. Except for the first one and partially for the second, however, all the other would cause our estimates to be overestimates, and therefore the conclusion of very low impact of viral lysis on prokaryotes in salterns would not be affected.

\section{Square archaea and lemon-shaped viruses}

The square archaea were first observed by Walsby (1980) in the salt-saturated brines of a sabkha (salt plain) in the Southern Sinai Peninsula. Since then these cells have been found in other hypersaline habitats in Israel, Spain, California (USA) and Senegal. These prokaryotes have not been grown in pure cultures (Oren 1994), but there is no doubt that these organisms are halophilic archaea (Stoeckenius 1981). In the absence of any convincing laboratory cultures, it is not possible to tell whether more than 1 type exists (Grant \& Larsen 1989).

In samples from salt-saturated brines, it is common to find a series of odd morphologies, including cupshaped, square, rectangular and triangular cells. Al- though several box-shaped archaea have been isolated in pure cultures from similar environments (Javor et al. 1982), they were more variable in appearance and smaller than Walsby's square archaea and they lacked gas vacuoles (Parkes \& Walsby 1981). No information is available about the phages of any of these halophilic archaea.

We found a clear pattern of increasing square archaeal abundance with increasing salinity. In the saltiest ponds this morphotype formed a large percentage of the cell number (25\%). Thus, they could be expected to play a significant role in the ecosystem.

We did not find any significant difference among the percentages of visibly infected square archaea with increases in their abundance. This indicates a constant proportion between uninfected cells and infected cells We could not estimate in situ growth rates specifically for this group, thus we could not calculate rates of mortality for them as we did before with the whole prokaryotic community. However, applying Proctor et al.'s conversion factors to the percentage of square archaea visibly infected we could estimate the total percentage of infection for the square archaea. Thus, from 5 to $48 \%$ of the square archaea could be infected by viruses at any moment. Of course, the conversion factors of Proctor et al. (1993) were calculated for a marine Vibrio. The real factor for the square archaea could be completely different. In any case, the number of square archaea is rather constant in salterns: we have found the same abundance in different years and in different salterns (Fig. 5A). The persistence of these numbers with relatively high infection suggests that the viruses do not have a strong impact on the abundance of square archaea.

Different mechanisms may work in the maintenance of this equilibrium. It has already been mentioned that carrier states can be very important in the salterns. Since the square archaea were the only infected morphotype in the most salty ponds, this may indicate that they were the most metabolically active component of the prokaryotic assemblage. Moreover, they are halophilic archaea and in the saltiest ponds they find the best conditions for growth (Oren 1994). From the halophage-halophilic archaea pairs studied in cultures, it is known that when the halophilic archaea reach their optimal growth conditions, a carrier state is often established. This situation seems to protect halophilic archaea from extensive phage-induced lysis, and provides for the perpetuation of the phage (Torsvik \& Dundas 1980). Thus, a high percentage of infected square archaea would not necessarily cause high mortality in their population.

We have also found a particular morphotype of virus infecting the square archaea, the 'lemonshaped viruses'. Similarly shaped viruses have been 
isolated from other archaea: Sulfolobus B12 and Methanococcus voltae (Zillig et al. 1988), but have not been isolated or described in halophilic archaea. It is interestung that it has been suggested that this type of VLP could have arisen before the separation of the major branches of the archaeal domain (Zillig et al. 1988).

Throughout the salinity gradient we have been able to follow the viral infection from a situation where bacterivores and viruses interacted with prokaryotes up to a high salinity environment where only prokaryotes and viruses were present. This study of viruses in salterns supports a general conclusion about their role in steady-state situations: the viruses are not important in determining overall bacterial abundance. However, more work is necessary in order to know how the populations can remain in such high abundance. Studies related to the diversity and activity of the different bacterial assemblages are necessary. The salterns seem to be an appropriate environment to test some of these hypotheses.

Acknowledgements. We thank all the people of the Department of Microbiology, University of Bergen, for their great help. Special thanks are due to E. S. Erichsen from the laboratory for Electron Microscopy at the same University for his help with TEM work. This work has been supported by DGICYT grant PB91-075 and European Union grant DIADEME (MAS2-CT93-0077). J.L.C.-P. and N.G.-B. were supported by Fl scholarships from the 'Generalitat de Catalunya'

\section{LITERATURE CITED}

Bell R (1993) Estimating production of heterotrophic bacterioplankton via incorporation of tritiated thymidine. In: Kemp PF, Sherr BF, Sherr EB, Cole JJ (eds) Handbook of methods in aquatic microbial ecology. Lewis Publishers, Boca Raton, p 495-503

Billen G, Servais P, Becquevort S (1990) Dynamics of bacterioplankton in oligotrophic and eutrophic environments: bottom-up or top-down control? Hydrobiologia 207:37-42

Borsheim KY, Bratbak G. Heldal M (1990) Enumeration and biomass estimation of planktonic bacteria and viruses by transmission electron microscopy. Appl Environ Microbiol 56:352-356

Bratbak G, Heldal M (1993) Total count of viruses in aquatıc environment. In: Kemp PF, Sherr BF, Sherr EB, Cole JJ (eds) Handbook of methods in aquatic microbial ecology. Lewis Publishers. Boca Raton, p 135-138

Bratbak $G$, Heldal M. Thingstad TF, Riemann B, Haslund $\mathrm{OH}$ (1992) Incorporation of viruses into the budget of microbial C-transfer, A first approach. Mar Ecol Prog Ser 83: $273-280$

Calvo C, García de la Paz A, Bejar V, Quesada E, RamosCormezana A (1988) Isolation and characterization of phage F9-11 from a lysogenic Deleya halophila strain. Curr Microbiol 17:49-53

Cochlan WP, Wikner J, Steward GF, Smith DC, Azam F (1993) Spatial distribution of viruses, bacteria and chlorophyll a in neritic, oceanic and estuarine environments. Mar Ecol Prog Ser 92:77-87
Daniels LL, Wais AC (1990) Ecophysiology of bacteriophage S5100 infecting Halobacterium cutirubrum. Appl Environ Microbiol 56:3605-3608

Fuhrman JA, Noble RT (1995) Viruses and protusts cause similar mortality in coastal seawater Limnol Oceanogr $40(7)$ : $1236-1242$

Fuhrman JA. Suttle CA (1993) Viruses in marine planktonic systems. Oceanography 6:51-63

Grant WD, Larsen H (1989) Group III. Extremely halophilic archaeobacteria. Order Halobacteriales. Ord. Nov. In: Staley JT (ed) Bergey's manual of systematic bacteriology, Vol 3. Williams \& Wilkins, Baltimore, p 2216-2233

Heldal M. Bratbak G (1991) Production and decay of viruses in aquatic environments. Mar Ecol Prog Ser 72: $205-212$

Hennes KP. Simon M (1995) Significance of bacteriophages for controlling bacterioplankton growth in a mesotrophic lake. Appl Environ Microbiol 61:333-340

Javor BJ, Requadt C, Stoeckenius W (1982) Box-shaped halophilic bacteria. J Bacteriol 151:1532-1542

Maranger R, Bird. DF (1995) Viral abundances in aquatic systems: a comparison between marine and fresh waters. Mar Ecol Prog Ser 121.217-226

Mathias CB, Kirschner AKT, Velimirov B (1995) Seasonal variations of virus abundance and viral control of the bacterial population in backwater system of the Danube river. Appl Environ Microbiol 61:3734-3740

Nagata T, Kirchman DL (1992) Release of dissolved organic matter by heterotrophic protozoa: implications for microbial food webs. Arch Hydrobiol 35:99-109

Oren A (1994) The ecology of the extremely halophilic archaea. FEMS Microb Rev 13:415-440

Pace ML (1988) Bacterial mortality and the fate of bacterial production. Hydrobiologia 159:41-50

Pace ML, MacManus GB. Findlay SEG (1990) Planktonic community structure determines the fate of bacterial production in a temperate lake. Limnol Oceanogr 35:795-808

Parkes K, Walsby AE (1981) Ultrastructure of a gas-vacuolate square bacterium. J Gen Microb 126:503-506

Pauling $C$ (1982) Bacteriophages of Halobactenum halobium: isolation from fermented fish sauce and primary characterization. Can J Microbiol 28:916-928

Proctor LM, Fuhrman JA (1990) Viral mortality of marine bacteria and cyanobacteria. Nature 343:60-62

Proctor LM, Fuhrman JA (1992) Mortality of marine bacteria in response to enrichments of the virus size fraction from seawater. Mar Ecol Prog Ser 87:283-293

Proctor LM, Okubo A, Fuhrman JA (1993) Calibrating estimates of phage-induced mortality in marine bacteria: ultrastructural studies of marine bacteriophage development from one-step growth experiments. Microb Ecol 25 $161-182$

Rodríguez-Valera F (1988) Characteristics and microbial ecology of hypersaline environments. In: Rodriguez-Valera $F$ (ed) Halophulic bactena, Vol I. CRC Press, Boca Raton, p $3-30$

Salat J, Marrasé C (1994) Exponential and linear estimation of grazing on bacteria: effects of changes in the proportion of marked cells. Mar Ecol Prog Ser 104:205-209

Schnabel H, Zillig W, Pfafflee M, Snabel R, Michel H, Delius $\mathrm{H}$ (1982) Halobacterium halobium phage $\phi \mathrm{H}$. EMBO J 1: $87-92$

Sherr BF, Sherr EB, Fallon RD (1987) Use of monodispersed. fluorescently labeled bacteria to estimate in situ protozoan bacterivory. Appl Environ Microbiol 53:958-965

Sherr BF, Sherr EB, Pedrós-Alió C (1989) Simultaneous measurement of bacterioplankton production and protozoan 
bacterivory in estuarine water. Mar Ecol Prog Ser 54: 209-219

Steward GF, Smith DC, Azam F (1996) Abundance and production of bacteria and varuses in the Bering and Chukchi Seas. Mar Ecol Prog Ser 131:287 300

Steward GF, Wikner J, Cochlan WP, Smith DC, Azam F (1992) Estimation of virus production in the sea: II. Field results. Mar Microb Food Webs 6:79-90

Stoeckenus W (1981) Walsby's square bacterium: fine structure of an orthogonal procaryote. J Bacteriol 148:352-360

Suttle CA (1993) Enumeration and isolation of viruses. In: Kemp PF, Sherr BF, Sherr EB, Cole JJ (eds) Handbook of methods in aquatic microbial ecology. Lewis Publishers, Boca Raton, p 121-133

Taylor GT, Iturriaga R, Sullivan CW (1985) Interactions of bacterivorous grazers and heterotrophic bacteria with dissolved organic matter. Mar Ecol Prog Ser 23:129-141

Torsvik T, Dundas ID (1980) Persisting phage infection in Halobacterium salinarium str.1. J Gen Virol 47:29-36

Vaqué D, Gasol JM, Marrasé C (1993) Grazing rates on bacteria: the significance of methodology and ecological factors. Mar Ecol Prog Ser 109:263-274

Wais AC, Kon M, MacDonald RE, Stollar BD (1975) Salt dependent bacteriophage infecting Halobacterium cutiru-

Responsible Subject Editor: J. Fuhrman, Los Angeles, California, USA brum and H. halobium. Nature 256:314-315

Walsby AE (1980) A square bacterium. Nature 283:69-71

Weinbauer MG, Fuks D, Peduzzi P (1993) Distribution of viruses and dissolved DNA along a coastal trophic gradient in the Northern Adriatic Sea. Appl Environ Microb 59: $4074-4082$

Weinbauer MG, Peduzzi P (1994) Frequency, size and distribution of bacteriophages in different marine bacterial morphotypes. Mar Ecol Prog Ser 108:11-20

Weinbauer MG, Peduzzi P (1995a) Significance of viruses versus heterotrophic nanoflagellates for controlling bacterial abundance in the Northern Adriatic Sea. J Plankton Res $17: 1851-1856$

Weinbauer MG, Peduzzi P (1995b) Effect of virus-rich high molecular weight concentrates of seawater on the dynamics of dissolved amino acids and carbohydrates. Mar Ecol Prog Ser 127:245-253

Woese CR, Kandler O, Wheelis ML (1990) Towards a natural system of organisms: proposal for the domains archaea, bacteria and eukarya. Prod Nat Acad Sci USA 87. $4576-4579$

Zillig W, Reiter W, Palm P, Gropp F, Neumann H, Rettenberg $M$ (1988) Viruses of Archaeobacteria. In: Calender R (ed) The bacteriophages. Plenum Press, New York, p 517-558

Manuscript first received: May 8, 1996

Revised version accepted: September 16, 1996 